\title{
Proximal chemical characterization and antioxidant activity of Persea americana leaves $c v$ Hass, Fuerte y Criollo
}

\section{Caracterización químico proximal y actividad antioxidante de las hojas de Persea americana cv Hass, Fuerte y Criollo}

FRAUSTO MOLINA, Janette†, TOVAR JIMÉNEZ, Xochit1*, ÁLVAREZ GARCÍA, Rocío* and TÉLLEZ JURADO, Alejandro

Universidad Politécnica de Pachuca. Bioactive Compound Technology Laboratory. C. P. 43830, Ex-Hacienda de Santa Bárbara, Carretera Pachuca - Cd. Sahagún Km.20, Zempoala, Hidalgo, Mexico.

ID $1^{\text {st }}$ Author: Janette, Frausto-Molina / ORC ID: 0000-0002-5630-413X, CVU CONACYT ID: 782517

ID $1^{\text {st }}$ Coauthor: Xochitl, Tovar-Jiménez / ORC ID: 0000-0002-6626-6237, CVU CONACYT ID: 228873

ID $2^{\text {nd }}$ Coauthor: Rocío, Álvarez-García / ORC ID: 0000-0001-7573-3290, CVU CONACYT ID: 201058

ID $3^{\text {rd }}$ Coauthor: Alejandro, Téllez-Jurado / ORC ID: 0000-0002-5491-3679, CVU CONACYT ID: 30605

DOI: $10.35429 /$ EJE.2020.12.7.1.7

Received January 10, 2020; Accepted June 30, 2020

\begin{abstract}
The aim of this work was to determine the proximal chemical composition of leaves and infusion Persea americana $c v$ Hass, Fuerte and Criollo, as well as, their antioxidant activity by standardized analytical methods. To carry this out, $P$. americana leaves were analyzed according to moisture content (fresh and dehydrated), only in the sampling area from Criollo variety was found that produced green and purple fruits, therefore, the leaves of these trees were also evaluated, in order to determine if the proximal composition and antioxidant activity depends on these factors. The results indicated that there is a statistically significant difference in the proximal composition between $P$. americana leaves of the three varieties evaluated, as well as, their antioxidant activity, with dry leaves infusion of the Criollo variety with green fruit showing the highest activity antioxidant $(70 \%$ Inhibition $\mathrm{ABTS}^{+\bullet}$ ).
\end{abstract}

Hojas de Persea americana, Análisis proximal, Actividad antioxidante

\begin{abstract}
Resumen
El objetivo del presente trabajo fue determinar la composición químico proximal de las hojas e infusión de Persea americana de las variedades Hass, Fuerte y Criollo, así como, su actividad antioxidante por medio de métodos analíticos estandarizados. Para llevar acabo esto, las hojas de $P$. americana se analizaron de acuerdo al contenido de humedad (frescas y deshidratadas) y sólo en la zona de muestreo de la variedad Criollo se encontró que esta variedad producia frutos de color verde y morado, por lo cual, las hojas de estos árboles tambien fueron evaluadas, con la finalidad de determinar si la composición proximal y actividad antioxidante depende de estos factores. Los resultados indicaron que existe diferencia estadísticamente significativa en la composición proximal entre las hojas de $P$. americana de las tres variedades evaluadas, al igual que, su actividad antioxidante, siendo la infusión de hojas deshidratadas de la variedad Criollo de fruto verde la que presentó mayor actividad antioxidante $\left(70 \%\right.$ Inhibición $\left.\mathrm{ABTS}^{+*}\right)$.
\end{abstract}

Persea americana leaves, Proximal analysis, Antioxidant activity

Citation: FRAUSTO-MOLINA, Janette, TOVAR-JIMÉNEZ, Xochitl, ÁLVAREZ-GARCÍA, Rocío and TÉLLEZJURADO, Alejandro. Proximal chemical characterization and antioxidant activity of Persea americana leaves $c v$ Hass, Fuerte y Criollo. ECORFAN Journal-Ecuador. 2020. 7-12:1-7.

*Correspondence to Autor (E-mail: xtovar@upp.edu.mx)

$\dagger$ Researcher contributing as first author. 


\section{Introduction}

Persea americana (avocado) is an arboreal species native to Mexico and Central America, it belongs to the Lauraceae family and is classified into four subspecies or horticultural races according to its place of origin: Guatemalan $(P$. americana var. Guatemalensis), Antillean ( $P$ americana var. drymifolia), Mexican ( $P$. americana var. americana) and Costa Rican ( $P$. americana var. costaricensis), which have different morphological characteristics and environmental conditions (SIAP-SAGARPA, 2017; Campos-Rojas, 2011).

When the interbreeding between these subspecies takes place it is known as hybridization and the descendant product acquires characteristics that allow a better adaptation to climatic conditions, as well as fruits with different sensory characteristics (SAGARPA, 2011), which influence its proximal chemical composition.

In this sense, the avocado has around 100 varieties and mainly in Mexico it is considered a medicinal plant (Pérez-Álvarez et al., 2015). Specifically, the leaves of this species are used as flavoring and flavoring in Mexican gastronomy, while the infusion of avocado leaf has several therapeutic properties such as: antioxidant, digestive, analgesic, antitussive, among others.

Despite this, some studies have been carried out on its proximal composition and biological properties, however, in most cases the horticultural race or hybridization studied is not indicated, so it is relevant to carry out this study in the varieties of commercial importance (Hass and Fuerte cv), as well as, in the variety used in the traditional indigenous medicine of Mexico (Criollo cv) (Campos-Rojas, 2011; Yasir et al., 2010; Ezejiofor et al., 2013; Adaramola et al., 2016; Oboh et al., 2016).
In addition, the proximal chemical analysis of a food is the starting point in the evaluation of the macronutrient content so that it can be related to the best combination of some raw material and reach the desired level of the different components of a diet, also considering that the nutritional quality of plant products depends on the micro and macronutrients and on the presence of certain bioactive antioxidant compounds that may have a complementary or superimposed mechanism of action on health and that varies considerably due to environmental, genetic and plant-related factors.

Due to the aforementioned, the objective of this work was to determine the proximal chemical composition of the leaves and infusion of Persea americana from the Hass, Fuerte and Criollo varieties, as well as its antioxidant activity by means of standardized analytical methods.

\section{Methodology}

\section{Preparation of plant material}

The leaves of $P$. americana were collected according to the NOM-109-SSA1-1994 standard.

The sampling area of the Criollo variety belongs to the municipality of Papantla, Veracruz because in this place the leaves are used for therapeutic purposes, for this, samples of endemic trees were taken that produced fruits of different colors (green and purple) with characteristics that correspond to the Criollo variety. While the leaves of the commercial varieties Hass and Fuerte were collected in the municipality of Meztitlan, Hidalgo, in orchards established for commercialization.

In all cases, the leaves were cleaned and divided into two groups, one group was used to perform the fresh analysis and the other group for the analysis with dehydrated leaves.

\section{Infusion of $P$. americana leaves}

It was obtained from the fresh and dehydrated leaves of $P$. americana of the Hass, Fuerte and Criollo varieties by decoction of $30 \mathrm{~g}$ of sample in $1 \mathrm{~L}$ of water for $10 \mathrm{~min}$. 


\section{Proximal chemical analysis of the leaves and infusion of $P$. americana}

It was carried out according to the methodology described by the Association Official of Analytical Chemists (AOAC, 1990).

Humidity: It was carried out according to that described in method No. 925.09, the calculation was carried out according to equation (1):

Humidity $(\%)=\frac{\mathrm{W}_{\text {sample }}-\mathrm{W}_{\text {final }}}{W_{\text {sample }}} \times 100$

\section{Where:}

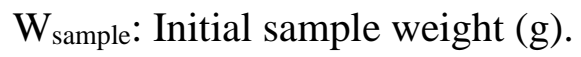

$\mathrm{W}_{\text {final }}$ : Weight of dry sample $(\mathrm{g})$.

Ash: It was carried out by means of the gravimetric method No. 923.03. The ash content was obtained by weight difference, for which equation (2) was used:

Ashes $(\%)=\frac{\mathrm{W}_{\text {sample }}-\mathrm{W}_{\text {final }}}{W_{\text {sample }}} \times 100$

\section{Where:}

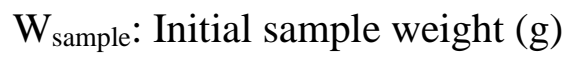

$\mathrm{W}_{\text {final }}$ : Weight of ashes $(\mathrm{g})$

Fats: The determination was carried out in a Soxhlet equipment following the methodology described in method No. 920.39. The weight difference expressed the percentage of fat and was calculated by means of the following equation (3):

Fats $(\%)=\frac{W_{\text {fats }}}{W_{\text {sample }}} \times 100$

Where:

$\mathrm{W}_{\text {sample: Initial sample weight }(\mathrm{g})}$

$\mathrm{W}_{\text {final }}$ : Weight of fats $(\mathrm{g})$

Raw fiber: It was carried out according to method No. 962.09, which consists of taking $1 \mathrm{~g}$ of vegetable sample $\left(\mathrm{W}_{0}\right)$ and adding $200 \mathrm{~mL}$ of $\mathrm{H}_{2} \mathrm{SO}_{4}(0.255 \mathrm{~N})$, bringing it to a boil for 1 minute. At the end of the acid digestion $4.54 \mathrm{~g}$ of $\mathrm{NaOH}$ were added and boiled for $1 \mathrm{~h}$.
Once the time had elapsed, the mixture was filtered with the help of a filter paper at constant weight $\left(\mathrm{W}_{1}\right)$, with known ash content $\left(\mathrm{W}_{2}\right)$, the filter paper was washed with hot water, to finally fold it and place it in a crucible at weight constant $\left(\mathrm{W}_{3}\right)$ to subject it to drying at $100{ }^{\circ} \mathrm{C}$ for $24 \mathrm{~h}$ (constant weight $\mathrm{W}_{4}$ ), subsequently it was brought to ash at $550{ }^{\circ} \mathrm{C}$ for $5 \mathrm{~h}$, to finally weigh the sample $\left(\mathrm{W}_{5}\right)$. Crude fiber is expressed as a percentage and was calculated according to the following equations (4-6):

$P F=W_{4}-W_{3}-W_{1}$

$P C=W_{5}-W_{3}-W_{2}$

Raw fiber $(\%)=\frac{(P F-P C)}{W_{0}} \times 100$

Where:

$\mathrm{W}_{1}$ : Filter paper weight.

$\mathrm{W}_{2}$ : Weight of ash on filter paper.

$\mathrm{W}_{3}$ : Weight of porcelain capsule.

$\mathrm{W}_{4}$ : Weight of the porcelain capsule with filter paper and the crude fiber residue.

$\mathrm{W}_{5}$ : Weight of the porcelain capsule with the ashes from the crude fiber and the filter paper.

PF: Weight of crude fiber and ash.

PC: Weight of ashes from crude fiber.

$\mathrm{W}_{0}$ : Weight of the plant sample.

Total protein: It was carried out according to method No. 960.52. The result is reported as a percentage of total protein and the correction factor 6.25 was used (equation 7,8 ).

$N_{\text {total }}(\%)=\frac{\left(H C l_{m}-H C l_{B}\right)(0.14)(H C l)}{W_{\text {sample }}} \times 100$

Total protein $(\%)=N_{\text {total }} \times 6.25$

Where:

HClm: Volume of hydrochloric acid spent in the sample. 
HClB: Volume of hydrochloric acid spent on the blank.

HCl: Normality of hydrochloric acid.

$\mathrm{W}_{\text {sample: }}$ Initial sample weight.

Total carbohydrates: They were quantified by means of the phenol-sulfuric method described by Dubois et al., (1956).

\section{Antioxidant activity of the infusion of $P$. americana leaves}

At $20 \mu \mathrm{L}$ of the infusion, $980 \mu \mathrm{L}$ of the ABTS + - radical were added, the mixture was incubated at $25{ }^{\circ} \mathrm{C}$ in the dark for $7 \mathrm{~min}$, after the time the absorbance was measured at $754 \mathrm{~nm}$. The results were expressed as a percentage of inhibition of the radical ABTS $+\bullet$ (Miller et al., 1996).

\section{Statistic analysis}

The analysis of multiple comparison of means was carried out by the honest significant difference (HSD) method proposed by Tukey using a significance level of 0.05 and the Statistica Statsoft software vs. 7.0.

\section{Results}

\section{Proximal chemical analysis of $P$. americana leaves}

Graphic 1 shows the results of the proximal chemical analysis carried out on the fresh leaves of $P$. americana $c v$ Hass, Fuerte and Criollo, where it is observed that there is no statistically significant difference ( $p>0.05$; adjusted R2: 0.89 ) in the content of total carbohydrates in the evaluated samples, as well as in the crude fiber content only for the CVFr, HFr and FFr samples (p> 0.05; R2 adjusted: 0.72), on the other hand, the total protein content is statistically different among all the analyzed samples ( $\mathrm{p}<0.05$; R2adjusted: 0.99), however, the fresh leaves of the Criollo variety that produces purple fruits (CMFr) present higher total protein content (8.72 \pm 0.01 ), while the CVFr sample is the one that It has higher moisture content $(53.62 \pm 0.5)$ and lower fat content $(1.00 \pm 0.01)$.

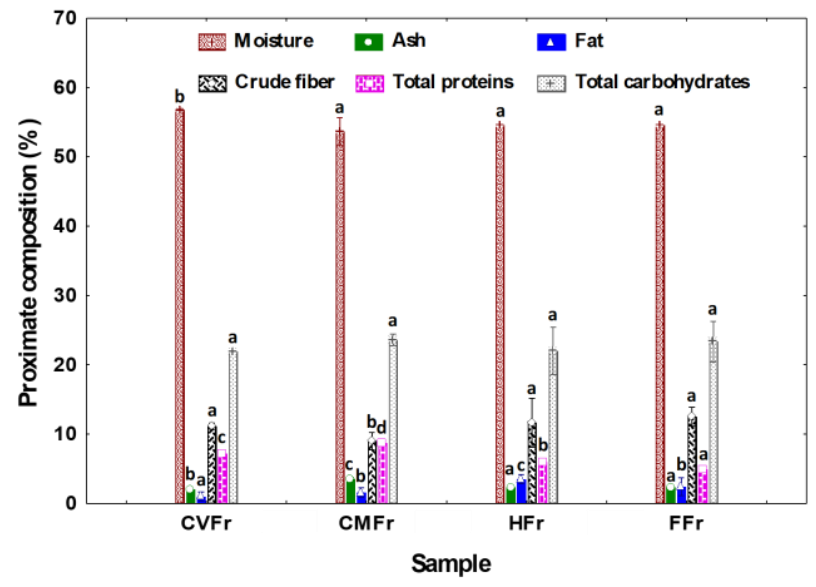

Graphic 1 Proximal analysis of fresh leaves of Persea americana $c v$ Hass, Fuerte and Criollo

CVFr: Fresh leaves of P. americana cv Criollo with green fruit; CMFr: Fresh leaves of $P$. americana cv Criollo with purple fruit; HFr: Fresh leaves of $P$. americana cv Hass; FFr: Fresh leaves of $P$. americana cv Fuerte.

Equal letters indicate that there is no statistically significant difference ( $p>0.05)$.

Regarding the proximal chemical composition of the dehydrated samples, in Graphic 2 it is observed that the leaves of $P$. americana cv Criollo are the ones with the highest content of total carbohydrates, total protein and fat, while the content of crude fiber does not present statistically significant difference between the samples evaluated ( $p>$ 0.05 ; adjusted $\mathrm{R}^{2}$ : 0.88). On theñp other hand, the dehydrated leaves of the commercial varieties (Hass and Fuerte) are those with the highest moisture content $(54.55 \pm 0.01)$.

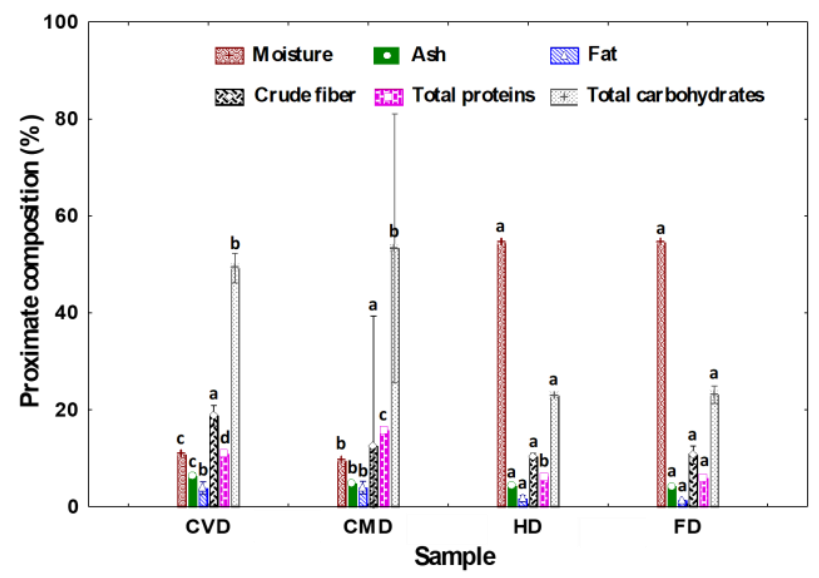

Graphic 2 Proximal analysis of the dehydrated leaves of Persea americana cv Hass, Fuerte and Criollo

CVD: Dehydrated leaves of $P$. americana cv Criollo with green fruit; CMD: Dehydrated leaves of $P$. americana $c v$ Criollo with purple fruit; HD: Dehydrated leaves of $P$. americana $c v$ Hass; FD: Dehydrated leaves of $P$. americana cv Fuerte. 
Equal letters indicate that there is no statistically significant difference ( $p>0.05)$.

In general, the differences found between the results of the studied varieties may be due to the agroclimatic conditions of the place where the plants grow and their age as indicated by Hussain et al., (2013). Likewise, the results obtained in this work are different from those obtained in the literature (Asodu et al., 2010; Olaywola, 2013; Gbadamosi and Kalejaye, 2017), it is worth mentioning that in these publications neither the variety studied nor the conditions sample processing (Table 1). The results showed that the main components found in the analyzed samples were total carbohydrates and crude fiber, in this sense, the three varieties analyzed indicate that the crude fiber content ( $20 \%$ ) makes the leaves of $P$. americana can be used for animal feed, in the paper industry and also at the level of the human digestive system, where it would help eliminate waste and toxins, in addition to reducing cholesterol, preventing diseases in the small intestine (Yasir et al., 2010; Ezejiofor et al., 2013; Adaramola et al., 2016; Oboh et al., 2016).

\begin{tabular}{|l|r|r|r|}
\hline \multicolumn{1}{|c|}{$\begin{array}{c}\text { Component } \\
(\mathbf{\%})\end{array}$} & \multicolumn{1}{c|}{$\begin{array}{c}\text { Asodu } \text { et } \\
\boldsymbol{a l} . \mathbf{},\end{array}$} & \multicolumn{1}{c|}{$\begin{array}{c}\text { Olaywola } \\
\mathbf{( 2 0 1 3 )}\end{array}$} & $\begin{array}{c}\text { Gbadamosi } \\
\text { \& Kalejaye } \\
(\mathbf{2 0 1 7})\end{array}$ \\
\hline Humidity & $5.0 \pm 2$ & $9.1 \pm 0.1$ & $9.3 \pm 0.2$ \\
\hline Ashes & $20.3 \pm 3.4$ & 2.9 & $3.4 \pm 0.2$ \\
\hline Fats & $13.9 \pm 6.4$ & $1.3 \pm 0.1$ & $6.5 \pm 0.2$ \\
\hline Crude fiber & $40.1 \pm 6$ & $2.9 \pm 0.1$ & $8.5 \pm 0.2$ \\
\hline Total protein & $26.4 \pm 5.2$ & $9.8 \pm 0.1$ & $21.6 \pm 0.2$ \\
\hline $\begin{array}{l}\text { Total } \\
\text { carbohydrates }\end{array}$ & $13.9 \pm 6.4$ & $74.2 \pm 0.4$ & $50.7 \pm 0.2$ \\
\hline
\end{tabular}

Table 1 Proximal analysis of $P$. americana leaves

Table 2 shows the proximal analysis carried out on the infusion of fresh leaves of $P$. americana cv Hass, Fuerte and Criollo, where it is observed that in most of the components there is a statistically significant difference between the infusions of the varieties studied $(p>0.05)$, however, there is no statistical difference in the content of crude fiber and total carbohydrates $(\mathrm{p}$ $<0.05 ; \mathrm{R}^{2}$ adjusted: 0.98), regarding the higher total protein content is presented in the I-CMFr and I-FFr samples $(0.6 \pm 0.1$ and $0.7 \pm 0.1$, respectively).

\begin{tabular}{|c|c|c|c|c|}
\hline \multirow{2}{*}{$\begin{array}{c}\text { Component } \\
(\%)\end{array}$} & \multicolumn{4}{|c|}{ Sample } \\
\hline & I-CVFr & I-CMFr & I-HFr & I-FFr \\
\hline & $96.9 \pm 0.1^{\mathrm{a}}$ & $96.9 \pm 0.1^{\mathrm{a}}$ & $97.1 \pm 0.1^{\mathrm{b}}$ & $96.8 \pm 0.1^{\mathrm{a}}$ \\
\hline Humidity & $0.3 \pm 0.0^{\mathrm{a}}$ & $0.3 \pm 0.0^{\mathrm{a}}$ & $0.3 \pm 0.0^{\mathrm{b}}$ & $0.3 \pm 0.0^{\mathrm{a}}$ \\
\hline Ashes & $0.1 \pm 0.0^{\mathrm{a}}$ & $0.1 \pm 0.0^{\mathrm{a}}$ & $0.2 \pm 0.0^{\mathrm{c}}$ & $0.1 \pm 0.0^{\mathrm{b}}$ \\
\hline Fats & $0.5 \pm 0.4^{\mathrm{a}}$ & $0.5 \pm 0.4^{\mathrm{a}}$ & $0.5 \pm 0.2^{\mathrm{a}}$ & $0.5 \pm 0.3^{\mathrm{a}}$ \\
\hline Raw fiber & $0.4 \pm 0.1^{\mathrm{a}}$ & $0.6 \pm 0.1^{\mathrm{b}}$ & $0.4 \pm 0.1^{\mathrm{a}}$ & $0.7 \pm 0.1^{\mathrm{b}}$ \\
\hline Total protein & $1.9 \pm 0.5^{\mathrm{a}}$ & $1.6 \pm 0.3^{\mathrm{a}}$ & $1.5 \pm 0.1^{\mathrm{a}}$ & $1.5 \pm 0.4^{\mathrm{a}}$ \\
\hline
\end{tabular}

Table 2 Proximal analysis of the infusion of fresh leaves of $P$. americana cv Hass, Fuerte and Criollo

I-CVFr: Infusion of fresh leaves of $P$. americana $\mathrm{cv}$ Criollo with green fruit; I-CMFr: Infusion of fresh leaves of $P$. americana $\mathrm{cv}$ Criollo with purple fruit; I-HFr: Infusion of fresh leaves of $P$. americana cv Hass; I-FFr: Infusion of fresh leaves of $P$. americana cv Fuerte.

In Table 3 it is observed that the dehydration process of the leaves of $P$. americana cv Hass, Fuerte and Criollo negatively affects the content of total carbohydrates, total protein and fats, this in comparison with the infusions of the fresh leaves evaluated (Table 2). On the other hand, the crude fiber content in the I-HD and I-FD samples is higher than in the Criollo variety leaves both dehydrated and fresh.

The differences in the proximal analysis of the infusion of $P$. americana leaves may be due to the processing carried out on the sample, as indicated by Valdez-Solana et al., (2015), since the dehydration process can modify the content of carbohydrates, crude fiber and fat, mainly because fatty acids can undergo slow degradation processes and proteins and carbohydrates can react with each other causing browning reactions (Maillard reaction) (Venkatesan et al., 2006).

\begin{tabular}{|c|c|c|c|c|}
\hline $\begin{array}{l}\text { Component } \\
\text { (\%) }\end{array}$ & $\begin{array}{l}\text { Sample } \\
\text { I-CVD }\end{array}$ & I-CMD & I-HD & I-FD \\
\hline Humidity & $97.0 \pm 0^{\mathrm{a}}$ & $96.9 \pm 0.1^{\mathrm{a}}$ & $97.1 \pm 0.1^{\mathrm{b}}$ & $96.9 \pm 0.1^{\mathrm{a}}$ \\
\hline Ashes & $0.3 \pm 0^{\mathrm{a}}$ & $0.3 \pm 0^{\mathrm{a}}$ & $0.3 \pm 0^{\mathrm{a}}$ & $0.3 \pm 0^{\mathrm{a}}$ \\
\hline Fats & $0.03 \pm 0^{\mathrm{b}}$ & $0.05 \pm 0^{\mathrm{a}}$ & $0.04 \pm 0.0^{\mathrm{a}}$ & $0.03 \pm 0^{b}$ \\
\hline Raw fiber & $0.4 \pm 0^{\mathrm{a}}$ & $0.1 \pm 0.1^{\mathrm{a}}$ & $0.8 \pm 0.3^{\mathrm{b}}$ & $0.6 \pm 0.4^{b}$ \\
\hline Total protein & $0.3 \pm 0.1^{\mathrm{b}}$ & $0.2 \pm 0^{\mathrm{a}}$ & $0.3 \pm 0.1^{\mathrm{b}}$ & $0.2 \pm 0^{\mathrm{a}}$ \\
\hline Total carbohydrates & $2.0 \pm 0.1^{\mathrm{b}}$ & $2.4 \pm 0.3^{\mathrm{b}}$ & $1.5 \pm 0.0^{\mathrm{a}}$ & $2.0 \pm 0.4^{\mathrm{b}}$ \\
\hline
\end{tabular}

Table 3 Proximal analysis of the infusion of dehydrated leaves of $P$. americana cv Hass, Fuerte and Criollo 
I-CVD: Infusion of dehydrated leaves of $P$. americana cv Criollo with green fruit; ICMD: Infusion of dehydrated leaves of $P$. americana cv Criollo with purple fruit; I-HD: Infusion of dehydrated leaves of $P$. americana cv Hass; I-FD: Infusion of dehydrated leaves of $P$. americana cv Fuerte.

\section{Antioxidant activity of the infusion of $P$. americana leaves}

Regarding the antioxidant activity, it is observed in Figure 3 that the infusion of the dehydrated leaves of $P$. americana cv Hass, Fuerte and Criollo present greater antioxidant activity with respect to fresh leaves, likewise, the green fruit variety Criollo (I-CVD) is the one with the highest activity (70.28 \pm 1.22$)$, however, in the infusion of fresh leaves (I-CVFr) its activity decreases $(28.90 \pm 0.92)$.

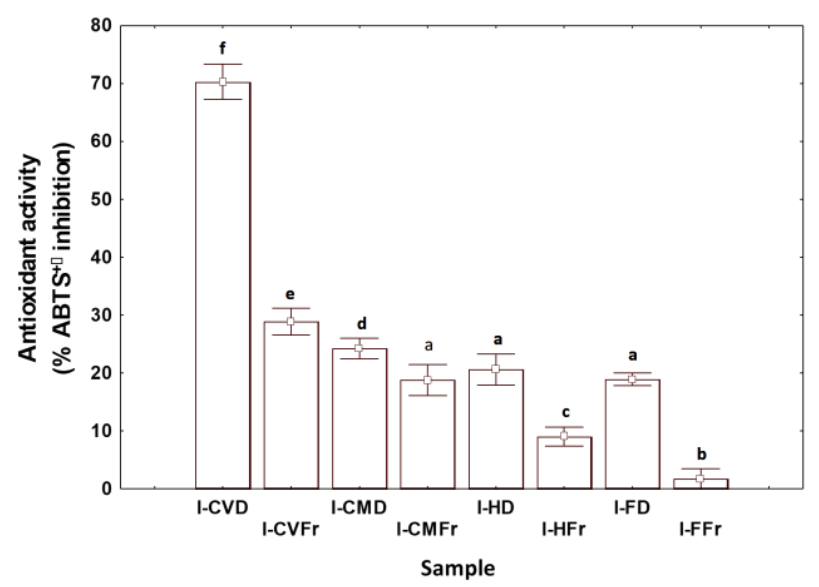

Graphic 3 Antioxidant activity of the infusion of fresh and dehydrated leaves of $P$. americana cv Hass, Fuerte and Criollo

I-CVD: Infusion of dehydrated leaves of P. americana cv Criollo with green fruit; I-CVFr: Infusion of fresh leaves of P. americana cv Criollo with green fruit; I-CMD: Infusion of dehydrated leaves of $P$. americana cv Criollo with purple fruit; I-CMFr: Infusion of fresh leaves of $P$. americana cv Criollo with purple fruit; I-HD: Infusion of dehydrated leaves of $P$. americana cv Hass; I-HFr: Infusion of fresh leaves of $P$. americana cv Hass; I-FD: Infusion of dehydrated leaves of P. americana cv Fuerte; I-FFr: Infusion of fresh leaves of $P$. americana cv Fuerte.

Equal letters indicate that there is no statistically significant difference ( $p>0.05)$.

\section{Conclusions}

The results indicated that there is a statistically significant difference in the proximal composition between the leaves of $P$. americana of the three varieties evaluated, as well as between the Criollo variety with green and purple fruit. Likewise, the infusion of dehydrated leaves of the green fruit Criollo variety (I-CVD) was the sample that presented the highest antioxidant activity $(70 \%$ ABTS $+\bullet$ Inhibition).

Therefore, the leaves of $P$. americana could help the development of new products with a high content of crude fiber, having a favorable impact on human health, preventing or delaying gastrointestinal diseases such as intestinal obstruction and cancer. While the ICVD infusion for its antioxidant activity could be used in the pharmaceutical industry to produce products with medicinal properties.

\section{References}

Adaramola B., Onigbinde A. y Shokunbi O. (2016). Physiochemical properties and antioxidant potential of Persea americana seed oil. Chemistry International, 2(3); 168-175.

AOAC. 1990. Official Methods of Analysis. 15 ed. USA. $40-68$

Asodu M., Asaolu S., Adanlawo I Aluko, B., Alli-Smith Y. y Abidakun, A. Michael. (2010). Comparative chemical compositions of the leaves of some selected antihypertensive medicinal plants in Nigeria. Der Pharma Chemica, 2(2); 11-15.

Campos-Rojas E. (2011). El aguacate (Persea americana) una especie muy mexicana. Agroproductividad. 27-35.

Dubois M., Gilles K. A., Hamilton J. K., Rebers P. T. y Smith F. (1956). Colorimetric method for determination of sugars and related substances. Analytical chemistry, 28(3), 350356.

Ezejiofor, A., Okorie, A. y Orisakwe, O. (2013). Hypoglycaemic and tissue-protective effects of the aqueous extract of Persea americana seeds on alloxan-induced albino rats. The Malaysian Journal of Medical Sciences, 20(5), 31-39. 
Gbadamosi I. y Kalejaye, A.O. (2017). Comparison of the antioxidant activity, phytochemical and nutritional contents of two antihypertensive ethnomedicinal plants. Ife Journal of Science, 19(1), 147-158.

Hussain J., Rehman U., Al-Harrasi A., Ali L., Khan A. L. y Albroumi, M. (2013). Essential oil composition and nutrient analysis of selected medicinal plants in Sultanate of Oman. Asian Pacific Journal of Tropical Disease, 3(6); 421428. http://doi.org/10.1016/S2222-1808 (13)60095-X.

Miller N. J., Rice-Evans C. A y Paganga G. (1996). Structure-antioxidant activity relationships of flavonoids and phenolic acids. Free Radical Biology \& Medicine. 20(7): 933956.

NOM-109-SSA1-1994. Norma Oficial Mexicana. Procedimientos para la toma, manejo y transporte de muestras de alimentos para su análisis microbiológico.

Oboh G., Odubanjo V. O., Bello F., Ademosun A. O., Oyeleye S. I., Nwanna E. E., y Ademiluyi A. O. (2016). Aqueous extracts of avocado pear (Persea americana Mill.) leaves and seeds exhibit anti-cholinesterases and antioxidant activities in vitro. Journal Of Basic And Clinical Physiology And Pharmacology, 27(2), 131-140.

Pérez-Álvarez S., Ávila Q. G., y Coto A., O. (2015). El aguacatero (Persea americana Mill). Cultivos Tropicales, 36(2); 111-123.

SAGARPA. (2011). Aguacate. Monografía de cultivos.1-10.

SIAP-SAGARPA (2017). Anuario estadístico de la producción agrícola 2017. Sitio web: :https://www.gob.mx/cms/uploads/attachment/f ile/302238/Boletin_mensual_producci_n_de_ag uacate_enero_2018.pdf

Valdez-Solana A., Mejía-García Y., TéllezValencia A., García-Arenas G., Salas-Pacheco J., Alba-Romero J., Sierra-Campos E. (2015). Nutritional content and elemental and phytochemical analyses of Moringa oleifera grown in Mexico. Journal of Chemistry. (2015);1-9.
Venkatesan, S., Senthurpandian V., Murugesan S., Maibuam W. y Ganapathy M. (2006). Quality standards of CTC black teas as influenced by sources of potassium fertiliser. Journal of the Science of Food and Agriculture, 86(5): 799803.

Yasir M., Das S., y Kharya M. (2010). The phytochemical and pharmacological profile of Persea Americana Mill. Pharmacognosy Reviews, 4 (7); 77-84. http://doi.org/10.4103/0973-7847.65332. 